\title{
Dynamical Hybrid System for Optimizing and Controlling Efficacy of Plant-Based Protein in Aquafeeds
}

\author{
Serge Dossou, ${ }^{1,2}$ Mahmoud A. O. Dawood $\mathbb{D}^{3,4}$ Amr I. Zaineldin, ${ }^{5}$ Ibrahim A. Abouelsaad, ${ }^{6,7}$ \\ Kumbukani Mzengereza ${ }^{D},{ }^{1}$ Ronick S. Shadrack, ${ }^{1}$ Yukun Zhang, \\ Mohamed El-Sharnouby, ${ }^{8}$ Hamada A. Ahmed, ${ }^{9}$ and Mohammed F. El Basuini $\mathbb{D}^{7,10}$ \\ ${ }^{1}$ Laboratory of Aquatic Animal Nutrition, Faculty of Fisheries, Kagoshima University, 4-50-20, Kagoshima 890-0056, Japan \\ ${ }^{2}$ Laboratoire D'Hydrobiologie et D'Aquaculture, Faculté des Sciences Agronomiques, Université D'Abomey Calavi, \\ 01 BP 526 Cotonou, Benin \\ ${ }^{3}$ Department of Animal Production, Faculty of Agriculture, Kafrelsheikh University, Kafr El-Sheikh 33516, Egypt \\ ${ }^{4}$ The Center for Applied Research on the Environment and Sustainability, The American University in Cairo, Cairo 11835, Egypt \\ ${ }^{5}$ Animal Health Research Institute (AHRI-DOKI), Giza, Egypt \\ ${ }^{6}$ Horticulture Department, Faculty of Agriculture, Damanhour University, Damanhour, Egypt \\ ${ }^{7}$ Faculty of Desert Agriculture, King Salman International University, South Sinai 46618, Egypt \\ ${ }^{8}$ Department of Biotechnology, College of Science, Taif University, P. O. Box 11099, Taif 21944, Saudi Arabia \\ ${ }^{9}$ Department of Nutrition and Veterinary Clinical Nutrition, Faculty of Veterinary Medicine, Damanhour University, \\ Damanhour, Egypt \\ ${ }^{10}$ Department of Animal Production, Faculty of Agriculture, Tanta University, Tanta 31527, Egypt
}

Correspondence should be addressed to Mohammed F. El Basuini; m_fouad_islam@yahoo.com

Received 10 March 2021; Accepted 24 April 2021; Published 3 May 2021

Academic Editor: Ahmed Mostafa Khalil

Copyright (C) 2021 Serge Dossou et al. This is an open access article distributed under the Creative Commons Attribution License, which permits unrestricted use, distribution, and reproduction in any medium, provided the original work is properly cited.

In this paper, a mathematical model was used to evaluate a dynamical hybrid system for optimizing and controlling the efficacy of plant-based protein in aquafeeds. Fishmeal (FM), raw rapeseed meal (RM), and a fermented meal with yeast (RM-Yeast) and fungi (Aspergillus oryzae RM-Koji) were used as test ingredients for the determination of apparent digestibility coefficients (ADCs) of dry matter, crude protein, crude lipid, energy, and essential amino acids (EAA) for olive flounder (Paralichthys olivaceus, $7 \pm 0.02 \mathrm{~g}$ ) using diets containing $0.5 \% \mathrm{Cr}_{2} \mathrm{O}_{3}$ as an inert indicator. Among all ingredients tested, FM had the maximum ADC of dry matter $(P<0.05)$, protein $(P<0.05)$, lipid $(P>0.05)$, and energy $(P>0.05)$. Fermented meals (RM-Yeast and RM-Koji) showed higher ADC $(P<0.05)$ of crude protein compared with RM, while there was no significance in ADCs of crude lipid and energy among different forms of rapeseed meal. Besides, ADC of crude lipid for RM-Yeast and RM-Koji, on the one hand, and ADC of gross energy for RM-Yeast, on the other hand, were not varied from that for FM $(P>0.05)$. Amino acid digestibility reflects protein digestibility in most cases. Interestingly, protease, lipase, and amylase activities were better expressed in RM-Koji, RM-Yeast, and FM over RM, respectively. The current results deliver important information on nutrients and energy bioavailability in raw and fermented RM, which can be implemented to accurately formulate applied feeds for olive flounder. Compared with other applicable systems, the complexity of the approach implemented has been considerably reduced.

\section{Introduction}

Because of the rising cost and demand for fishmeal on the international market, consideration has been given to increasing the use of plant origin protein sources in cultured fish feeds $[1,2]$. For decades, soybean meal has become the most vastly used plant protein meal in aquaculture [3], and more protein sources, such as rapeseed meal, are being investigated as promising candidates for aquafeeds [4]. Indeed, rapeseed meal (RM) has become the second most 
markedly traded protein source of plant origin after soybean due to booming global production/supply (40.51 million metric tonnes in 2017) [5]. Rapeseed meals have substantial potential as a fishmeal substitute in aquafeeds because of their protein contents (32\% to $45 \%$ ) and amino acid profile compared with soybean meal $[6,7]$. However, owing to the prevalence of antinutritional factors (ANFs) and high fiber levels in rapeseed meals [8], its use has been imperfect, with the main adverse effects in fish being reduced palatability, feed intake, and digestibility [9].

To separate protein fractions from remaining ingredients, including ANFs, various approaches have been implemented, but each has its own set of downsides, such as protein loss and denaturation, expense, commercial viability, and environmental sustainability [10]. Microbial fermentation practice has been described as a less expensive and more efficient option. Indeed, during fermentation, microbial activities can partially degrade ANFs like cell walls and phytates, as well as breaking down large molecules, for example, starch and protein. into smaller molecules that are easier to digest and absorb [11-13]. So far, there is a widespread agreement that, after fermentation, nutrient bioavailability in rations for different animals amplifies [14-19]. Nonetheless, the performance of this substitution varies greatly depending on the fish species and experimental conditions. Changing dietary feedstuffs without affecting the animal's performance also necessitates knowledge of the feedstuff composition, especially the apparent digestibility coefficients of the nutrients.

Paralichthys olivaceus, also known as the olive flounder, is a commercially remarkable fish that is extensively farmed in Asia. ADCs of different protein sources for olive flounder have already been investigated in recent studies [20-24]. However, there is no accessible information on the digestibility of rapeseed products for this species. Therefore, this study sought to determine rapeseed meal digestibility and whether microbial fermentation of the meal could enhance nutrients digestibility and digestive enzymes in olive flounders.

\section{Materials and Methods}

2.1. Experimental Diets. The indicator approach (chromic oxide $=\mathrm{Cr} 2 \mathrm{O} 3$ at $0.5 \%)$ was used to determine nutrient and energy digestibility (ADCs) in feedstuffs of test diets (TD) comprised of $70 \%$ basal or references diet (RD) $(54.45 \%$ crude protein and $14.75 \%$ lipid) and $30 \%$ of each of the test ingredients (Table 1). Fishmeal (FM) was used as the key protein contributor in the basal diet. Raw rapeseed meal (RM) and fermented meal with yeast (RM-Yeast) and fungi (Aspergillus oryzae RM-Koji) were used as test ingredients for ADCs. Commercially available FM and RM were used, while RM-Yeast and RM-Koji were made as previously mentioned [4, 25]. Ingredients proximate analysis and amino acid compositions are displayed in Table 2.

2.2. Fish and Feeding Trial. The trial was done at Kagoshima University's Kamoike Marine Production Laboratory
TABLE 1: Ingredients $(\mathrm{g} / \mathrm{kg})$ of basal and test diets.

\begin{tabular}{lcc}
\hline Ingredients & Basal diet & Test diets \\
\hline Fishmeal & 70 & 49 \\
Rapeseed meal forms & - & 30 \\
Wheat flour & 4 & 2.8 \\
Polack liver oil & 5 & 3.5 \\
Soybean lecithin & 4 & 2.8 \\
Vitamin mix & 3 & 3 \\
Mineral mix $^{3}$ & 3 & 3 \\
Stay-C $^{4}$ & 0.1 & 0.1 \\
Activated gluten $^{5}$ & 5 & 5 \\
$\alpha$-Cellulose & 4.4 & 2.63 \\
Attractant & 1 & 1 \\
$\mathrm{Cr}_{2} \mathrm{O}_{3}$ & 0.5 & 0.5 \\
\hline
\end{tabular}

${ }^{1}$ Rapeseed meal forms: rapeseed raw meal (RM), fermented rapeseed meal with yeast (RM-Yeast), or fungi (RM-Koji). ${ }^{2} \mathrm{~A}$ kilo of mixed vitamins contains biotin $(0.01 \mathrm{mg})$, Ca pantothenate $(0.27 \mathrm{mg})$, choline chloride $(7.87 \mathrm{mg})$, folic acid $(0.01 \mathrm{mg})$, inositol $(3.85 \mathrm{mg})$, niacin $(0.77 \mathrm{mg}), \mathrm{B}_{-}$ carotene $(0.10 \mathrm{mg})$, vitamin $\mathrm{B}_{1}(0.06 \mathrm{mg})$, vitamin $\mathrm{B}_{2}(0.19 \mathrm{mg})$, vitamin $\mathrm{B}_{6}$ $(0.05 \mathrm{mg})$, vitamin $\mathrm{B}_{12}(0.0001 \mathrm{mg})$, vitamin $D_{3}(0.01 \mathrm{mg})$, vitamin $E$ $(0.38 \mathrm{mg})$, vitamin $\mathrm{K}_{3}(0.05 \mathrm{mg}), \rho$-aminobenzoic acid $(0.38 \mathrm{mg})$, and cellulose $(1.92 \mathrm{mg}) .^{3} \mathrm{~A}$ kilo of mineral mixture contains $\mathrm{Al}(\mathrm{OH})_{3}(0.01 \mathrm{mg}), \mathrm{Ca}$ $\left(\mathrm{IO}_{3}\right)_{2}(0.01 \mathrm{mg})$, Ca lactate $(12.09 \mathrm{mg}), \mathrm{CoSO}_{4}(0.04 \mathrm{mg})$, Fe citrate $(1.1 \mathrm{mg})$, $\mathrm{K}_{2} \mathrm{HPO}_{4}(8.87 \mathrm{mg}), \mathrm{MgSO}_{4}(5.07 \mathrm{mg}), \mathrm{MnSO}_{4} \quad(0.03 \mathrm{mg}), \mathrm{Na}_{2} \mathrm{HPO}_{4}$ (3.23 mg), and $\mathrm{ZnSO}_{4}(0.13 \mathrm{mg}) .{ }^{4} \mathrm{~L}$-Ascrobil-2-phosphate-magnesium. ${ }^{5} \mathrm{~A}$ glu SS (Glico Nutrition Co., Ltd. Osaka, Japan).

(Japan). Flounder juveniles $(7 \pm 0.02 \mathrm{~g})$ were provided from a local private farm and adapted to test conditions for 10 days while fed the basal diet. Fishes $(n=120)$ were allocated in four experimental groups in triplicate (15 fish per tank) using 12 polycarbonates $100 \mathrm{~L}$ tanks supplied with a maximum of $80 \mathrm{~L}$ flow-through seawater, where tanks were prepared with an inlet, outlet, and constant aeration. During the entire trial, the natural light/dark regime was applied, while maintaining the water quality at the ideal limits in terms of temperature $\left(20.2 \pm 1.1^{\circ} \mathrm{C}\right)$, dissolved oxygen $(\mathrm{DO}=6.90 \pm 0.3 \mathrm{mg} / \mathrm{L})$, and $\mathrm{pH}(7.9 \pm 0.4)$. Hand-feeding was used to visible satiation twice a day $(9: 00$ and $16: 00 \mathrm{~h})$, and the daily feed supply and leftover feed, which was recovered 40 minutes after each feeding to avoid contamination with feces, were reported. Feces collection started seven days after feeding to enable all previously ingested materials to be evacuated and lasted four weeks until adequate samples were collected for chemical analysis. Due to the difficulty of collecting flounders' feces, which are semiliquid and therefore dissolve quickly in water, samples were collected four times a day $(10 \mathrm{~h}, 12 \mathrm{~h}, 14$, and $16 \mathrm{~h})$ by siphoning after the morning meal to limit the leaching of nutrients. Samples were immediately filtered through a filter paper (Whatman \# 1), gathered per tank, and quickly kept for nutrient contents investigation at $-20^{\circ} \mathrm{C}$.

2.3. Digestive Enzyme Activity. Fish were depleted of food for 24 hours at the trial end, and their intestines were washed in pure cold water, cut into small pieces, and pooled for enzyme activity analysis. For the analysis, $2 \mathrm{~g}$ of each group sample was homogenized in $5 \mathrm{~mL}$ Tris- $\mathrm{HCl}$ buffer $(50 \mathrm{mM}, \mathrm{pH} 8.0)$ and centrifuged at $10000 \mathrm{~g}$ and $4^{\circ} \mathrm{C}$ for 30 minutes. The supernatant was regarded as a crude enzyme solution and 
TABLE 2: The chemical composition and amino acids' profile of tested feedstuffs.

\begin{tabular}{|c|c|c|c|c|}
\hline \multirow{2}{*}{ Items } & \multicolumn{4}{|c|}{ Feedstuffs } \\
\hline & FM & $\mathrm{RM}$ & RM-Yeast & RM-Koji \\
\hline Crude protein & 65 & 40 & 46.84 & 46.78 \\
\hline Crude lipid & 8.2 & 2.66 & 2.02 & 1.96 \\
\hline Ash & 15.5 & 7.45 & 7.65 & 8.36 \\
\hline Fiber & 0.35 & 11.40 & 10.41 & 10.88 \\
\hline Gross energy $(\mathrm{kJ} / \mathrm{g})^{1}$ & ND & 17.01 & 16.90 & 17.81 \\
\hline Phytic acid $(\mathrm{g} / \mathrm{kg})$ & ND & 41.00 & 31.24 & 33.44 \\
\hline Glucosinolates $(\mu \mathrm{mol} / \mathrm{g})$ & ND & 120.45 & 112.81 & 108.40 \\
\hline \multicolumn{5}{|c|}{ Amino acid profile ( $\mathrm{g} / 100 \mathrm{~g}$ of a dry ingredient) } \\
\hline Arginine & 4.62 & 2.14 & 2.45 & 2.81 \\
\hline Histidine & 2.58 & 1.31 & 1.43 & 1.49 \\
\hline Isoleucine & 2.00 & 1.26 & 1.34 & 1.38 \\
\hline Leucine & 4.68 & 2.47 & 3.83 & 3.41 \\
\hline Lysine & 4.07 & 1.78 & 1.75 & 1.65 \\
\hline Methionine & 1.78 & 0.63 & 0.83 & 0.91 \\
\hline Phenylalanine & 3.18 & 2.15 & 1.46 & 1.47 \\
\hline Threonine & 2.74 & 1.68 & 2.00 & 1.93 \\
\hline Valine & 2.37 & 1.61 & 1.56 & 1.77 \\
\hline
\end{tabular}

${ }^{1}$ Calculated using multiplying combustion values $(23.6,39.5$, and $17.2 \mathrm{~kJ} / \mathrm{g}$ ) in ratios of protein, lipid, and carbohydrate, respectively.

was used to detect the activity of intestine enzymes [26]. Protease activity was detected with the protocol of Sigma's Nonspecific Protease Activity Assay, utilizing casein as a substrate [27]. Released fatty acids by triglyceride enzymatic hydrolysis in a stabilized olive oil emulsion were quantified to inspect lipase activity [28]. Amylase activity was examined using iodine to reveal nonhydrolyzed starch [29].

2.4. Analytical Approaches and Calculation Formulas. The basic AOAC methods [30] were used to analyze the proximate composition of feed ingredients, diets, and feces. Moisture was checked by oven-drying to a stable weight at $110^{\circ} \mathrm{C}$. Crude protein, crude lipids, crude fiber, and ash were assessed by methods of Kjeldahl, Soxhlet extraction, FiberCap procedure, and incineration for $4 \mathrm{~h}$ at $550^{\circ} \mathrm{C}$ in a muffle furnace, respectively. The concentration of $\mathrm{Cr} 2 \mathrm{O} 3$ in diets and feces was detected using the method of Furukawa and Tsukahara [31]. Amino acids' profile was obtained with high-performance liquid chromatography (Shimadzu Co., Kyoto, Japan) [32]. ANFs in test ingredients were examined in terms of glucosinolates by their alkaline degradation and ferricyanide reaction [33] and phytic acid content with a colorimetric technique [34].

The following formulas were used to computerize the $\mathrm{ADCs}$ for the nutrients and energy:

$$
\begin{aligned}
\mathrm{ADC}_{\text {nutrient }(\%)} & =100-\left(\frac{\% \mathrm{Cr}_{2} \mathrm{O}_{3 \text { diet }}}{\% \mathrm{Cr}_{2} \mathrm{O}_{3 \text { feces }}} \times \frac{\% \text { nutrient }_{\text {feces }}}{\% \text { nutrient }}\right), \\
\mathrm{ADC}_{\text {gross energy }(\%)} & =100-\left(\frac{\% \mathrm{Cr}_{2} \mathrm{O}_{3 \text { diet }}}{\% \mathrm{Cr}_{2} \mathrm{O}_{3 \text { feces }}} \times \frac{\text { gross energy }(\mathrm{kJ} / \mathrm{g})_{\text {feces }}}{\text { gross energy }(\mathrm{kJ} / \mathrm{g})_{\text {diet }}}\right), \\
\mathrm{ADC}_{\text {dry matter }(\%)} & =100-\left(100 \times \frac{\% \mathrm{Cr}_{2} \mathrm{O}_{3 \text { diet }}}{\% \mathrm{Cr}_{2} \mathrm{O}_{3 \text { feces }}}\right) .
\end{aligned}
$$

Test ingredients ADCs $\left(\mathrm{ADC}_{\mathrm{I}}\right)$ were determined according to the digestibility of the $\mathrm{RD}$ and $\mathrm{TD}$ using the equation of Bureau et al. [35].

$$
\mathrm{ADC}_{I}=\mathrm{ADC}_{I}+\left(\frac{0.7 D_{R}}{0.3 D_{I}} \times \frac{\mathrm{ADC}_{T}}{A D C_{R}}\right)
$$

where

$\mathrm{ADC}_{\mathrm{T}}=\mathrm{ADC}$ of the test diets

$A D C_{R}=A D C$ of the reference or basal diet
$D_{R}=\%$ nutrient or gross energy $(\mathrm{Kj} / \mathrm{g})$ of the reference diet

$D_{I}=\%$ nutrient or gross energy $(\mathrm{kJ} / \mathrm{g})$ of the test ingredients

2.5. Statistical Analysis. Data were statistically computerized using one way-ANOVA (Package SuperANOVA version 1.11, Abacus Concepts, Berkeley, USA). Data were displayed as means values plus/minus the standard error of the mean 
TABle 3: Nutrients and gross energy contents (\%) of the basal and tested diets.

\begin{tabular}{lcccc}
\hline Items & Basal diet & RM & RM-Yeast & RM-Koji \\
\hline Dry matter & $64.84 \pm 0.25^{\mathrm{b}}$ & $51.38 \pm 2.57^{\mathrm{a}}$ & $53.66 \pm 2.87^{\mathrm{a}}$ & $53.15 \pm 3.97^{\mathrm{a}}$ \\
Crude protein & $86.04 \pm 0.36^{\mathrm{c}}$ & $73.16 \pm 0.64^{\mathrm{a}}$ & $80.88 \pm 1.58^{\mathrm{b}}$ & $79.79 \pm 1.60^{\mathrm{b}}$ \\
Crude lipid & $85.64 \pm 0.35^{\mathrm{b}}$ & $72.06 \pm 2.38^{\mathrm{a}}$ & $81.20 \pm 3.53^{\mathrm{ab}}$ & \\
Gross energy & $81.07 \pm 0.62^{\mathrm{b}}$ & $67.92 \pm 3.10^{\mathrm{a}}$ & $73.97 \pm 1.41^{\mathrm{ab}}$ & $80.49 \pm 3.86^{\mathrm{ab}}$ \\
\hline
\end{tabular}

Values (mean $\pm \operatorname{SEM}, n=3$ ) within a row with common superscripts are not different $(P>0.05)$.

$(X \pm S$. E. $M)$. Duncan's multiple range test detected significant differences between means. Variations at $P<0.05$ are significant statistical differences.

\section{Results}

Table 2 represents the chemical composition and amino acids' content of tested feedstuffs used in the experimental rations. No phytic acid or glucosinolate contents were detected in FM, and the highest contents were in RM, while RM-Yeast and RM-Koji showed remarkably lower contents. FM has the highest amino acid contents, while RM-Yeast and RM-Koji amino acid compositions were better compared with RM, except for phenylalanine.

ADCs values for FM, RM, RM-Yeast, and RM-Koji in the test diets for olive flounders are shown in Table 3. FM has the highest ADC $(P<0.05)$ for dry matter $(64.84 \%)$, while the dry matter ADCs for the other ingredients were relatively lower but not meaningfully different from each other $(P>0.05)$. Similar trends were observed for ADC of crude lipid and energy with the exception that crude lipid coefficients were numerically closer to that of FM in the case of RM-Yeast and RM-Koji, while the energy coefficient was numerically closer to that of FM in the case of RM-Yeast. Only ADC of crude protein showed a clear pattern, in which FM recorded the highest coefficient among all treatments $(P<0.05)$, and RM-Yeast and RM-Koji together recorded also a greater coefficient $(P<0.05)$ than $\mathrm{RM}$.

Apparent availability coefficients (EAA \%) of amino acids in test ingredients for Japanese flounder are presented in Table 4. FM has superior amino acids EAA $(P<0.05)$, while $\mathrm{RM}$ recorded the lowest values. However, EAA recorded no noteworthy variances between FM and RM-Yeast for arginine, isoleucine, lysine, and valine. Moreover, there were no differences in the EAA between the different rapeseed forms for arginine and histidine. Also, RM-Yeast and RM-Koji showed the same availability of leucine and methionine.

Table 5 represents the enzyme activity in the intestine of flounder fish-fed test diets. Intestinal enzyme activities (protease, lipase, and amylase) in juveniles' flounders fed RM recorded minimal values, while the best activities were achieved with RM-Koji, followed by RM-Yeast and FM, respectively.

\section{Discussion}

The sustainability of aquaculture has become the endeavor of researchers' focus, especially providing ecofriendly solutions to overcome various production problems [36]. From a nutritional standpoint, dietary alteration is a notable way of amending animals' wellbeing and performance [37, 38]. The findings of this work provide a comprehensive assessment of the influence of processing plant meals on the bioactivity of nutrients from rapeseed products when given to olive flounders. The composition of the test ingredients had a substantial impact on the ADCs of different nutrients, for example dry matter, crude protein, and crude lipid, and energy. FM has the highest $\mathrm{ADC}(P<0.05)$, while there are no important variances for crude lipid and energy when compared with RM-Yeast and crude lipid when compared with RM-Koji. However, no variances $(P>0.05)$ were recorded for dry matter, crude lipid, and energy between different rapeseed forms, while RM-Yeast and RM-Koji together recorded a significantly higher protein coefficient than RM $(P<0.05)$. These results indicate that, at this addition level, Paralichthys olivaceus cannot excellently utilize $\mathrm{RM}$ and derivate in diets when compared with FM. This is consistent with the results of Nagel et al. [39], suggesting rapeseed-derived poor palatability and deterioration of the diets for juvenile turbot. In this trial, FM had a substantially higher ADC $(P<0.05)$ of dry matter than all the test diets.

The amount of fecal material produced is determined by the dry matter digestibility of the feed and plant protein meals are always associated with low-digestible materials and lower dry matter digestibility than FM, due in part to their content in ANFs [40]. Table 2 showed the reduced fiber, phytic acid, and glucosinolates levels in RM-Yeast and RMKoji. Nonstarch polysaccharides, fibers, glucosinolates, and phytic acids, which also make up a large part of RM, are the main plant ingredients that contribute the most to digestive disability and waste production. The nutritional quality of $\mathrm{RM}$ is primarily determined by the presence of glucosinolates and phytic acids, which have been shown to have an unfavorable influence on feed taste, intake, and absorption $[41,42]$. There were some main variations in the digestibility of amino acids, but EAA digestibility reflects protein digestibility in general. Despite that, once again FM recorded numerically the highest EAA for all amino acids, while RM recorded the lowest. Protein digestion in fish can be hampered by high phytic acid levels combined with high fiber levels $[8,43,44]$. The effect of fiber on nutrient digestibility is thought to interfere with nutrient mobility along the gastrointestinal tract, resulting in limited nutrient absorption ability. Riche et al. [45] showed that phytates form complexes with proteins reducing the availability of amino-acids.

In the current trial, RM-Yeast and RM-Koji surprisingly recorded either numerically or significantly higher (in the case of protein ADC) digestibility coefficients than RM. These findings are in line with what has been found in fish enzyme activities. Intestinal enzyme activities (protease, 
TABLE 4: Apparent availability coefficients (\%) of amino acids in test ingredients for Japanese flounder*

\begin{tabular}{lcccc}
\hline Amino acids & & \multicolumn{3}{c}{ Ingredients } \\
& FM & RM & RM-Yeast & RM-Koji \\
\hline Arginine & $91.97 \pm 0.84^{\mathrm{b}}$ & $70.81 \pm 1.58^{\mathrm{a}}$ & $79.82 \pm 8.71^{\mathrm{ab}}$ & $77.03 \pm 0.12^{\mathrm{ab}}$ \\
Histidine & $89.41 \pm 1.29^{\mathrm{b}}$ & $73.79 \pm 0.31^{\mathrm{a}}$ & $82.33 \pm 0.52^{\mathrm{b}}$ & $76.00 \pm 0.52^{\mathrm{a}}$ \\
Isoleucine & $88.60 \pm 3.25^{\mathrm{b}}$ & $67.42 \pm 1.26^{\mathrm{a}}$ & $82.32 \pm 2.99^{\mathrm{b}}$ & $74.40 \pm 1.15^{\mathrm{a}}$ \\
Leucine & $92.16 \pm 1.80^{\mathrm{c}}$ & $71.26 \pm 1.28^{\mathrm{a}}$ & $84.03 \pm 0.41^{\mathrm{b}}$ & $78.68 \pm 0.23^{\mathrm{b}}$ \\
Lysine & $90.26 \pm 1.91^{\mathrm{b}}$ & $68.83 \pm 1.17^{\mathrm{a}}$ & $79.87 \pm 0.67^{\mathrm{b}}$ & $70.94 \pm 3.53^{\mathrm{a}}$ \\
Methionine & $88.37 \pm 1.15^{\mathrm{c}}$ & $65.51 \pm 1.05^{\mathrm{a}}$ & $80.98 \pm 0.12^{\mathrm{c}}$ & $75.09 \pm 3.35^{\mathrm{b}}$ \\
Phenylalanine & $91.41 \pm 0.50^{\mathrm{d}}$ & $66.88 \pm 1.68^{\mathrm{a}}$ & $82.14 \pm 0.13^{\mathrm{b}}$ & $74.04 \pm 0.02^{\mathrm{b}}$ \\
Threonine & $91.99 \pm 0.08^{\mathrm{c}}$ & $69.50 \pm 0.50^{\mathrm{a}}$ & $81.59 \pm 0.79^{\mathrm{b}}$ & $72.77 \pm 2.22^{\mathrm{a}}$ \\
Valine & $88.70 \pm 2.26^{\mathrm{b}}$ & $66.97 \pm 0.23^{\mathrm{a}}$ & & $69.99 \pm 3.44^{\mathrm{a}}$ \\
\hline
\end{tabular}

Values (mean $\pm \operatorname{SEM}, n=3)$ within a row with nonshared superscripts are different $(P<0.05)$.

TABLe 5: Enzyme activity (U/mg) in the intestine of Japanese flounder fed test diets.

\begin{tabular}{lcccc}
\hline Parameters & \multicolumn{4}{c}{ Ingredients } \\
& FM & RM & RM-Yeast & RM-Koji \\
\hline Protease & $0.33 \pm 0.02^{\mathrm{ab}}$ & $0.27 \pm 0.53^{\mathrm{a}}$ & $0.34 \pm 0.10^{\mathrm{ab}}$ & $0.45 \pm 0.04^{\mathrm{b}}$ \\
Lipase & $0.54 \pm 0.05^{\mathrm{ab}}$ & $0.37 \pm 0.06^{\mathrm{a}}$ & $0.59 \pm 0.12^{\mathrm{ab}}$ & $0.76 \pm 0.07^{\mathrm{b}}$ \\
Amylase & $0.82 \pm 0.03^{\mathrm{a}}$ & $0.59 \pm 0.15^{\mathrm{a}}$ & $0.83 \pm 0.27^{\mathrm{a}}$ & $1.13 \pm 0.06^{\mathrm{a}}$ \\
\hline
\end{tabular}

Values (mean $\pm \operatorname{SEM}, n=3$ ) within a row with various superscripts are different $(P<0.05)$.

lipase, and amylase) in juveniles' flounders fed RM recorded minimal values, while the best activities were achieved with RM-Koji, followed by RM-Yeast and then FM, respectively. These positive trends in groups fed RM-Yeast and RM-Koji over those fed simple RM could be attributable to the fermentation process and the reducing ANFs contents in the fermented ingredients. Murooka and Yamshita [46] explained that, during the fermentation process, Aspergillus oryzae not only produces a lot of enzymes but also has an extraordinarily good capacity to transform starches, proteins, and lipids into bioactive compounds. The fermentation process reduces the size of peptides, which lowers digestion's secretions level by producing more bioavailable items [11, 47]. According to Zhou et al. [48], peptide absorption in the gut, especially di- and tripeptides, is the main transport route for subsequent nitrogen utilization in fish. Increasing nutrient digestibility in various fermented meals has been already reported previously [21, 22, 49-53]. For precise feed formulation and regulation of aquaculture wastes, a reliable database on nutrient digestibility of various protein sources is essential $[54,55]$.

It could be concluded that poor nutrient digestibility due to the existence of ANFs is a significant limiting feature when simple RM was implemented as the main dietary protein source for P. olivaceus. However, feeding fish with fermented RM results in improved nutrients utilization supported with intestinal enzyme developments. Yet, it is necessary to conduct feeding trials over a longer period to check the performance, feed utilization, and optimum inclusion levels of these feedstuffs in diets for olive flounder. As future work, the most advanced computing models and artificial intelligence [56-60] can be applied to the sustainability of aquaculture.

\section{Data Availability}

The data used in this study are available upon request.

\section{Conflicts of Interest}

The authors declare that they have no conflicts of interest.

\section{Acknowledgments}

The first author acknowledges the contribution of Dr. Shunsuke Koshio and Dr. Manabu Ishikawa in supervising the experiment. This research was partially funded by the Management Expenses Grants of the United Graduate School of Agriculture Sciences, Kagoshima University, provided to Dr. Shunsuke Koshio. Moreover, this work was carried out using the facilities and materials in Taif University under Researchers Supporting Project number TURSP-2020/139, Taif University, Taif, Saudi Arabia.

\section{References}

[1] B. D. Glencross, M. Booth, and G. L. Allan, "A feed is only as good as its ingredients? a review of ingredient evaluation strategies for aquaculture feeds," Aquaculture Nutrition, vol. 13, no. 1, pp. 17-34, 2007.

[2] B. Van Vo, D. P. Bui, H. Q. Nguyen, and R. Fotedar, "Optimized fermented lupin (Lupinus angustifolius) inclusion in juvenile barramundi (Lates calcarifer) diets," Aquaculture, vol. 444, pp. 62-69, 2015.

[3] M. D. Hernández, F. J. Martínez, M. Jover, and B. García García, "Effects of partial replacement of fish meal by soybean meal in sharpsnout seabream (Diplodus puntazzo) diet," Aquaculture, vol. 263, no. 1-4, pp. 159-167, 2007.

[4] S. Dossou, S. Koshio, M. Ishikawa et al., "Effect of partial replacement of fish meal by fermented rapeseed meal on growth, immune response and oxidative condition of red sea bream juvenile, Pagrus major," Aquaculture, vol. 490, pp. 228-235, 2018.

[5] O. USDA, World Markets and Trade, US Dep. Agric. Foreign Agric. Serv., Washington, DC, USA, 2017.

[6] C. Burel, T. Boujard, F. Tulli, and S. J. Kaushik, "Digestibility of extruded peas, extruded lupin, and rapeseed meal in rainbow trout (Oncorhynchus mykiss) and turbot (Psetta maxima)," Aquaculture, vol. 188, no. 3-4, pp. 285-298, 2000.

[7] T. A. Woyengo, E. Beltranena, and R. T. Zijlstra, "Effect of anti-nutritional factors of oilseed co-products on feed intake 
of pigs and poultry," Animal Feed Science and Technology, vol. 233, pp. 76-86, 2017.

[8] F. Erdogan and M. Olmez, "Digestibility and utilization of canola meal in angel fish (P. scalare lichtenstein 1823) feeds," Journal of Animal and Veterinary Advances, vol. 9, no. 4, pp. 831-836, 2010.

[9] H. R. Enami, "A review of using canola/rapeseed meal in aquaculture feeding," Journal of Fisheries and Aquatic Science, vol. 6, no. 1, pp. 22-36, 2010.

[10] M. D. Drew, T. L. Borgeson, and D. L. Thiessen, "A review of processing of feed ingredients to enhance diet digestibility in finfish," Animal Feed Science and Technology, vol. 138, no. 2, pp. 118-136, 2007.

[11] K.-J. Hong, C.-H. Lee, and S. W. Kim, “Aspergillus oryzaeGB107 fermentation improves nutritional quality of food soybeans and feed soybean meals," Journal of Medicinal Food, vol. 7, no. 4, pp. 430-435, 2004.

[12] C. Shi, J. He, J. Yu et al., "Solid state fermentation of rapeseed cake with Aspergillus Niger for degrading glucosinolates and upgrading nutritional value," Journal of Animal Science and Biotechnology, vol. 6, no. 1, pp. 1-7, 2015.

[13] G. V. Jakobsen, B. B. Jensen, K. E. B. Knudsen et al., "Improving the nutritional value of rapeseed cake and wheat dried distillers grains with solubles by addition of enzymes during liquid fermentation," Animal Feed Science and Technology, vol. 208, pp. 198-213, 2015.

[14] A. Ahmed, I. Zulkifli, A. S. Farjam, N. Abdullah, J. B. Liang, and E. A. Awad, "Effect of solid state fermentation on nutrient content and ileal amino acids digestibility of canola meal in broiler chickens," Italian Journal of Animal Science, vol. 13, no. 2, pp. 3293-3414, 2014.

[15] P. Plaipetch and A. Yakupitiyage, "Effect of replacing soybean meal with yeast-fermented canola meal on growth and nutrient retention of Nile tilapia, Oreochromis niloticus (Linnaeus 1758)," Aquaculture Research, vol. 45, 2013.

[16] S. D. Upadhaya and I. H. Kim, "Ileal digestibility of nutrients and amino acids in unfermented, fermented soybean meal and canola meal for weaning pigs," Animal Science Journal, vol. 86, no. 4, pp. 408-414, 2015.

[17] H. Sun, J.-W. Tang, X.-H. Yao et al., "Partial substitution of fish meal with fermented cottonseed meal in juvenile black sea bream (Acanthopagrus schlegelii) diets," Aquaculture, vol. 446, pp. 30-36, 2015.

[18] H. D. Poulsen and K. Blaabjerg, "Fermentation of rapeseed meal, sunflower meal and faba beans in combination with wheat bran increases solubility of protein and phosphorus," Journal of the Science of Food and Agriculture, vol. 97, no. 1, pp. 244-251, 2017.

[19] X. Shi, F. Chen, G.-H. Chen et al., "Fishmeal can be totally replaced by a mixture of rapeseed meal andChlorellameal in diets for crucian carp (Carassius auratus gibelio)," Aquaculture Research, vol. 48, no. 11, pp. 5481-5489, 2017.

[20] J. Deng, K. Mai, Q. Ai et al., "Alternative protein sources in diets for Japanese flounder Paralichthys olivaceus (Temminck and Schlegel): II. Effects on nutrient digestibility and digestive enzyme activity," Aquaculture Research, vol. 41, no. 6, pp. 861-870, 2010.

[21] S.-J. Lim, S.-S. Kim, M.-A. Pham et al., "Effects of fermented cottonseed and soybean meal with phytase supplementation on gossypol degradation, phosphorus availability, and growth performance of olive flounder (Paralichthys olivaceus)," Fisheries and Aquatic Sciences, vol. 13, no. 4, pp. 284-293, 2010.
[22] S.-S. Kim, M. A. Pham, K.-W. Kim, M.-H. Son, and K.-J. Lee, "Effects of Microbial Fermentation of Soybean on growth performances, phosphorus availability, and antioxidant activity in diets for juvenile olive flounder (Paralichthys olivaceus)," Food Science and Biotechnology, vol. 19, no. 6, pp. 1605-1610, 2010.

[23] W. Chen, Q. Ai, K. Mai et al., "Effects of dietary soybean saponins on feed intake, growth performance, digestibility and intestinal structure in juvenile Japanese flounder (Paralichthys olivaceus)," Aquaculture, vol. 318, no. 1-2, pp. 95-100, 2011.

[24] M. M. Rahman, H.-S. Han, K.-W. Kim, K.-D. Kim, B.-J. Lee, and S.-M. Lee, "Apparent digestibility coefficients of the extruded pellet diets containing various fish meals for olive flounder, Paralichthys olivaceus," Fisheries and Aquatic Sciences, vol. 19, no. 1, p. 27, 2016.

[25] S. Dossou, S. Koshio, M. Ishikawa et al., "Growth performance, blood health, antioxidant status and immune response in red sea bream (Pagrus major) fed Aspergillus oryzae fermented rapeseed meal (RM-Koji)," Fish \& Shellfish Immunology, vol. 75, pp. 253-262, 2018.

[26] Y.-L. Shiu, S.-L. Hsieh, W.-C. Guei, Y.-T. Tsai, C.-H. Chiu, and C.-H. Liu, "UsingBacillus subtilisE20-fermented soybean meal as replacement for fish meal in the diet of orange-spotted grouper (Epinephelus coioides, Hamilton)," Aquaculture Research, vol. 46, no. 6, pp. 1403-1416, 2015.

[27] C. Cupp-Enyard, "Sigma's non-specific protease activity Assay-casein as a substrate," Journal of Visualized Experiments, vol. e899, no. 19, pp. 1-3, 2008.

[28] I. G. Borlongan, "Studies on the digestive lipases of milkfish, Chanos chanos," Aquaculture, vol. 89, no. 3-4, pp. 315-325, 1990.

[29] Worthington, W., Enzyme Manual, Worthington Biochemical Corporation, Lakewood, NJ, US, 1993.

[30] AOAC, Official Methods of Analysis of the Association of Official Analytical Chemists, Association of Official Analytical Chemists, Arlington, VA, USA, 15th edition, 1990.

[31] A. Furukawa and H. Tsukahara, "On the acid digestion method for the determination of chromic oxide as an index substance in the study of digestibility of fish feed," Nippon Suisan Gakkaishi, vol. 32, no. 6, pp. 502-506, 1966.

[32] S.-I. Teshima, A. Kanazawa, and M. Yamashita, "Dietary value of several proteins and supplemental amino acids for larvae of the prawn Penaeus japonicus," Aquaculture, vol. 51, no. 3-4, pp. 225-235, 1986.

[33] J. Jezek, B. G. D. Haggett, A. Atkinson, and D. M. Rawson, "Determination of glucosinolates using their alkaline degradation and reaction with ferricyanide," Journal of Agricultural and Food Chemistry, vol. 47, no. 11, pp. 4669-4674, 1999.

[34] W. Haug and H.-J. Lantzsch, "Sensitive method for the rapid determination of phytate in cereals and cereal products," Journal of the Science of Food and Agriculture, vol. 34, no. 12, pp. 1423-1426, 1983.

[35] D. Bureau, A. M. Harris, and C. Y. Cho, "Apparent digestibility of rendered animal protein ingredients for rainbow trout (Oncorhynchus mykiss)," Aquaculture, vol. 180, no. 3-4, pp. 345-358, 1999.

[36] M. F. El Basuini, S. A. Shahin, I. I. Teiba et al., "The influence of dietary coenzyme Q10 and vitamin C on the growth rate, immunity, oxidative-related genes, and the resistance against Streptococcus agalactiae of Nile tilapia (Oreochromis niloticus)," Aquaculture, vol. 531, Article ID 735862, 2021.

[37] B. A. Paray, M. F. El-Basuini, M. Alagawany, M. F. Albeshr, M. A. Farah, and M. A. O. Dawood, "Yucca schidigera usage 
for healthy aquatic animals: potential roles for sustainability,” Animals, vol. 11, no. 1, p. 93, 2021.

[38] M. A. O. Dawood, N. I. Abdel-Razik, M. S. Gewaily et al., " $\beta$-Glucan improved the immunity, hepato-renal, and histopathology disorders induced by chlorpyrifos in Nile tilapia," Aquaculture Reports, vol. 18, Article ID 100549, 2020.

[39] F. Nagel, T. Appel, C. Rhode, S. Kroeckel, and C. Schulz, "Blue mussel protein concentrate versus prime fish meal protein as a dietary attractant for turbot (psetta maxima L.) given rapeseed proteinbased diets," Journal of Aquaculture Research \& Development, vol. s2, p. 012, 2017.

[40] F. Kokou and E. Fountoulaki, "Aquaculture waste production associated with antinutrient presence in common fish feed plant ingredients," Aquaculture, vol. 495, pp. 295-310, 2018.

[41] G. Francis, H. P. S. Makkar, and K. Becker, "Antinutritional factors present in plant-derived alternate fish feed ingredients and their effects in fish," Aquaculture, vol. 199, no. 3-4, pp. 197-227, 2001.

[42] X. Yuan, Y. Zhou, X.-F. Liang et al., "Effect of dietary glutathione supplementation on the biological value of rapeseed meal to juvenile grass carp, Ctenopharyngodon idellus," Aquaculture Nutrition, vol. 21, no. 1, pp. 73-84, 2015.

[43] D. T. Ngo, I. Pirozzi, and B. Glencross, "Digestibility of canola meals in barramundi (Asian seabass; Lates calcarifer)," Aquaculture, vol. 435, pp. 442-449, 2015.

[44] S. A. Mwachireya, R. M. Beames, D. A. Higgs, and B. S. Dosanjh, "Digestibility of canola protein products derived from the physical, enzymatic and chemical processing of commercial canola meal in rainbow trout Oncorhynchus mykiss (Walbaum) held in fresh water," Aquaculture Nutrition, vol. 5, no. 2, pp. 73-82, 1999.

[45] M. Riche, N. L. Trottier, P. K. Ku, and D. L. Garling, “Apparent digestibility of crude protein and apparent availability of individual amino acids in tilapia (Oreochrois niloticus) fed phytase pretreated soybean meal diets," Fish Physiology and Biochemistry, vol. 25, no. 3, pp. 181-194, 2001.

[46] Y. Murooka and M. Yamshita, "Traditional healthful fermented products of Japan," Journal of Industrial Microbiology \& Biotechnology, vol. 35, no. 8, pp. 791-798, 2008.

[47] S.-K. Kim and I. Wijesekara, "Development and biological activities of marine-derived bioactive peptides: a review," Journal of Functional Foods, vol. 2, no. 1, pp. 1-9, 2010.

[48] J. S. Zhou, Y. S. Chen, H. Ji, and E. M. Yu, "The effect of replacing fish meal with fermented meal mixture of silkworm pupae, rapeseed and wheat on growth, body composition and health of mirror carp (Cyprinus carpio var. Specularis)," Aquaculture Nutrition, vol. 23, no. 4, pp. 741-754, 2017.

[49] S.-S. Kim, G. B. Galaz, M. A. Pham et al., "Effects of dietary supplementation of a meju, fermented soybean meal, and Aspergillus oryzae for juvenile parrot fish (oplegnathus fasciatus)," Asian-Australasian Journal of Animal Sciences, vol. 22, no. 6, pp. 849-856, 2009.

[50] E. Bartkiene, V. Krungleviciute, G. Juodeikiene, D. Vidmantiene, and Z. Maknickiene, "Solid state fermentation with lactic acid bacteria to improve the nutritional quality of lupin and soya bean," Journal of the Science of Food and Agriculture, vol. 95, no. 6, pp. 1336-1342, 2015.

[51] I. Ilham, F. Hapsari, and R. Fotedar, "Growth, enzymatic glutathione peroxidase activity and biochemical status of juvenile barramundi (Lates calcarifer) fed dietary fermented lupin meal supplemented with organic selenium," Aquaculture Research, vol. 49, no. 1, pp. 151-164, 2018.

[52] B. Koo, J. W. Kim, and C. M. Nyachoti, "Nutrient and energy digestibility, and microbial metabolites in weaned pigs fed diets containing Lactobacillus -fermented wheat," Animal Feed Science and Technology, vol. 241, pp. 27-37, 2018.

[53] R. Pieper, W. Hackl, U. Korn, A. Zeyner, W. B. Souffrant, and B. Pieper, "Effect of ensiling triticale, barley and wheat grains at different moisture content and addition of Lactobacillus plantarum (DSMZ 8866 and 8862) on fermentation characteristics and nutrient digestibility in pigs," Animal Feed Science and Technology, vol. 164, no. 1-2, pp. 96-105, 2011.

[54] S.-M. Lee, "Apparent digestibility coefficients of various feed ingredients for juvenile and grower rockfish (Sebastes schlegeli)," Aquaculture, vol. 207, no. 1-2, pp. 79-95, 2002.

[55] Y.-C. Yuan, S.-Y. Gong, H.-J. Yang, Y.-C. Lin, D.-H. Yu, and Z. Luo, "Apparent digestibility of selected feed ingredients for Chinese sucker, Myxocyprinus asiaticus," Aquaculture, vol. 306, no. 1-4, pp. 238-243, 2010.

[56] M. Zidan, H. Eleuch, and M. Abdel-Aty, "Non-classical computing problems: toward novel type of quantum computing problems," Results in Physics, vol. 21, Article ID 103536, 2021.

[57] M. Zidan, "A novel quantum computing model based on entanglement degree," Modern Physics Letters B, vol. 34, no. 35, Article ID 2050401, 2020.

[58] M. Zidan, A.-H. Abdel-Aty, D. M. Nguyen et al., "A quantum algorithm based on entanglement measure for classifying Boolean multivariate function into novel hidden classes," Results in Physics, vol. 15, Article ID 102549, 2019.

[59] W. Liu, Q. Wu, J. Shen, J. Zhao, M. Zidan, and L. Tong, "An optimized quantum minimum searching algorithm with suresuccess probability and its experiment simulation with Cirq," Journal of Ambient Intelligence and Humanized Computing, vol. 2021, 2021.

[60] A.-H. Abdel-Aty, H. Kadry, M. Zidan, Y. Al-Sbou, E. A. Zanaty, and M. Abdel-Aty, "A quantum classification algorithm for classification incomplete patterns based on entanglement measure," Journal of Intelligent \& Fuzzy Systems, vol. 38, no. 3, pp. 2809-2816, 2020. 